\title{
TOXICITIES OF INFLUENZA VACCINE: PERIPHERAL LEUKOCYTIC RESPONSE TO LIVE AND INACTIVATED INFLUENZA VIRUSES IN MICE*
}

\author{
Masami KUROKAWA, Setsuji ISHIDA, Sadao ASAKaWA, Saburo IWASA, \\ Norihisa GOTO and KazUo KURATSUKA \\ Department of General Biologics Control, National Institute of \\ Health, Kamiosaki, Shinagawa-ku, Tokyo 141, Japan
}

(Received: November 7, 1974)

\begin{abstract}
SUMMARY: Intraperitoneal or intravenous inoculation of live or inactivated influenza virus induced two characteristic responses of the peripheral leukocytes in mice, an early appearing leukopenic response and late appearing lymphopenia. The former response usually developed and subsided within several hours, though the change in leukocyte population was fairly complicated depending upon the activity of the inoculated material, while the latter began several hours after inoculation and reached its minimum level in 10 to $20 \mathrm{hr}$. The agent responsible for the former may be virus pyrogen, while the latter seems to be caused by some substance(s) other than that.

The early appearing leukopenic response was similar to that due to bacterial endotoxin in respect to the characteristic pattern of the change in peripheral leukocyte population, though it was relatively easy to distinguish one from the other by the length of the latent period and by the heat stability of the causative agent. Live or inactivated influenza virus causing the early appearing leukopenic response was found also to have the mouse body weight-decreasing toxicity.

The significance of these findings in the laboratory control test of influenza vaccine for untoward reactions often observed in human inoculated with some inactivated influenza vaccines was discussed. The possible roles of the two agents, virus pyrogen and endotoxin, in the febrile response were mentioned.
\end{abstract}

\section{INTRODUCTION}

It is well known that not only live but also some inactivated influenza viruses exhibit pyrogenicity in rabbits, though the activity of the latter is usually much lower than that of the former.

In addition to the pyrogenic activity, Harris and Henle (1948), Bennett, Wagner and Lequire (1949), and Wagner, Bennett and Lequire (1949) reported that iv injection of live influenza viruses caused lymphopenic rabbits. The time course of lymphopenia was apparently parallel with that of the febrile response. Kanoh and Kawasaki (1966) observed leukopenia in rabbits following iv injection of a live influenza virus.

\footnotetext{
* A part of the study was supported by and reported to the Research Committee on Influenza Vaccine.

黒川正身·石田説而·朝川貞雄·岩佐三郎·後藤紀久·倉塚和夫（国立予防衛生研究所 一般検定部）
} 
We observed that the activity of any endotoxin-containing material to produce changes in the peripheral leukocyte population in mice around $2 \mathrm{hr}$ after inoculation ran parallel to pyrogenicity in rabbits (Ishida, Ueno and Kurokawa, 1972; Ishida et al., 1972; Kurokawa et al., 1974). On account of the similarlity between pyrogenicity of bacterial endotoxin and that of virus pyrogen, we examined if influenza virus could induce any change in peripheral leukocyte population in mice.

This report describes some key findings concerning the characteristic leukocyte changes following inoculation of live or inactivated influenza virus in mice and preliminary investigations on some new methods for quantitative determination of toxicities of influenza vaccine.

\section{Materials ANd Methods}

Influenza virus: Virus strains, suppliers, and virus contents are listed in Table I. The values of CGA in the table were those given by the suppliers. All the materials were prepared from egg-grown and Sharples-centrifuged virus pools and proved to contain little endotoxin by the biological assay using leukopenic response in mice (Kurokawa et al., 1974). Inactivation of the viruses was performed with formaldehyde.

Endotoxin preparation: An endotoxin preparation, WE-1, extracted from Escherichia coli O-III by the phenol-water extraction method (Westphal and Jann, 1965) was used. The biological activities of this material were detailed in our separate paper (Ishida, 1968).

Test for peripheral leukocytic response in mice: Details of the methods for testing leukocytic response in mice have been described elsewhere (Kurokawa et al., 1974). Briefly, a material was injected intraperitoneally into conventional female mice of a random stock (ddY/S) at about 4 weeks of age. Allotment of mice to materials, doses of materials and date of bleeding or killing was at random. The blood specimen was taken from the tail vein and a cell suspension was made in

\section{TABLE I}

Influenza viruses used

\begin{tabular}{|c|c|c|c|c|c|}
\hline Code & $\begin{array}{c}\text { Live }(\mathrm{L}) \text { or } \\
\text { inactivated }(\mathrm{K})\end{array}$ & Name of strain & \multicolumn{2}{|c|}{ Concentration } & Supplier* \\
\hline S5 & $\mathrm{L}$ & A2/Fukuoka/1/70 & \multicolumn{2}{|c|}{$4332 \mathrm{CCA} / \mathrm{ml}$} & $\mathrm{KI}$ \\
\hline 714 & $\mathrm{~L}$ & $\mathrm{~B} /$ Osaka/2/70 & 3000 & $\prime \prime$ & $\mathrm{TP}$ \\
\hline B1 & $\mathrm{L}$ & A/Tokyo/1/72 & 1000 & $\prime \prime$ & RFMD \\
\hline $\mathbf{R}$ & $\mathrm{K}$ & A2/Aichi/2/68 & 1125 & $\prime \prime$ & " \\
\hline $\mathrm{Y}$ & $\mathrm{K}$ & B/Kagoshima/1/68 & 1775 & " & $\prime \prime$ \\
\hline $4 \mathrm{~A}-3$ & $\mathrm{~K}$ & A2/Fukuoka/1/70 & 3000 & $\prime \prime$ & "l \\
\hline 712 & $\mathrm{~K}$ & A2/Fukuoka/1/70 & 3000 & $\prime \prime$ & $\mathrm{TP}$ \\
\hline
\end{tabular}

* KI: Kitasato Institute

TP: Takeda Pharmaceutical Ltd., Hikari Plant

RFMD: Research Foundation for Microbial Diseases of Osaka University 
Millipore-filtered saline, to $10 \mathrm{ml}$ of which $0.1 \mathrm{ml}$ of $7 \%$ cethyltrimethyl ammonium chloride-glacial acetic acid solution (CAC) was added for cell counting or $0.3 \mathrm{ml}$ of $1 \%$ saponine-ethanol solution for cell sizing. Cell counting and cell sizing were performed with a Coulter counter model B (Coulter Electronic Inc., Florida, U.S.A.) with aperture of $100 \mu$. Differentiation of leukocytes was made microscopically on Giemsa-stained smears.

As evidences have accumulated to suggest that logarithmic transformation of number of peripheral leukocytes is a good choice for response metameter (Ishida and Kurokawa, 1971; Ishida, Ueno and Kurokawa, 1972; Kurokawa et al., 1974), leukocyte numbers were transformed into common logarithms for statistical analyses.

Test for pyrogenicity in rabbits: The method for the pyrogen test in the Minimum Requirements for Biological Products (Ministry of Health and Welfare, 1973 ) except for the observation time and the criteria for judgement was principally followed. Temperature recording was carried out every half hour for 5 to $6 \mathrm{hr}$ instead of hourly recording for $3 \mathrm{hr}$ suggested in the Requirements. Temperature rise in each rabbit was defined as the difference between the preinjection temperature and the highest temperature during the observation period. Negative values were recorded as 0 . When mean temperature rise of three rabbits was less than $0.55 \mathrm{C}$, the pyrogenicity of the test sample was judged as negative. If a test sample with positive pyrogenicity became negative after heating at $70 \mathrm{G}$ for $30 \mathrm{~min}$, the pyrogenic activity was regarded as heat labile and the test sample was interpreted to contain little endotoxin, if any.

The pyrogenicity was expressed, if necessary, in terms of minimal pyrogenic dose (MPD) defined as a dose inducing a mean temperature rise of $0.55 \mathrm{C}$ in three rabbits. For the estimation of MPD from mean temperature rise measured at one dose level, the regression coefficient of the log dose-temperature rise line estimated from the data of Dr. S. Kanoh (see Appendix) was tentatively applied. The coefficient for influenza pyrogen estimated in this way was about twice as large as that for endotoxin (Kurokawa et al., 1974). Some corrections of the values of MPD presented in this report might be needed in the future when much more information on the coefficient becomes available.

Test for body weight-decreasing toxicity in mice: A material was injected intraperitoneally into mice in $0.5 \mathrm{ml}$ and the body weight of each mouse was measured just before and daily after the injection. The body weight on a given day (the day $i$ )minus the initial body weight was referred to as BWDi (Ishida, 1968).

Results

\section{Pattern of Febrile Response of Rabbits to Virus Pyrogen}

Time course of febrile response of rabbits to live or inactivated influenza virus was similar to those presented in literatures (Bennett et al., 1949; Wagner et al., 1949; French, 1952). Examples of the characteristic pattern are shown in Fig. 1. There was a distinct latent period before onset of the febrile response, and the temperature peak appeared 3 to $5 \mathrm{hr}$ after inoculation (Fig. 1a and 1c). This 
a)
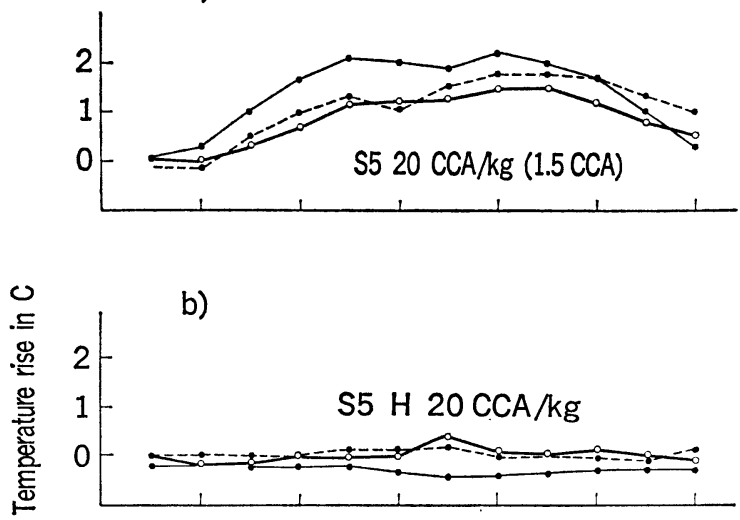

c)

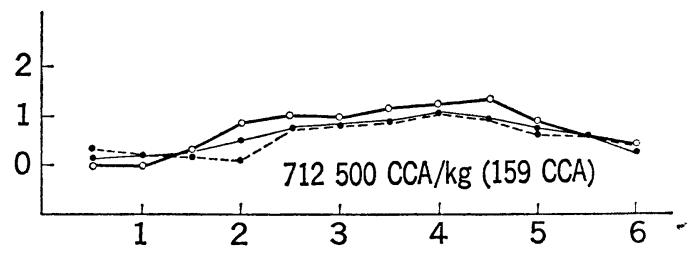

Hours after inoculation

Fig. 1 Characteristic pattern of the febrile response of rabbits to intravenous injection of live or inactivated influenza virus.

a. S5: live influenza virus $(20 \mathrm{CCA} / \mathrm{kg})$

b. S5H: S5 heat-inactivated at $70 \mathrm{C}$ for $30 \mathrm{~min}(20 \mathrm{CCA} / \mathrm{kg})$

c. 712: inactivated influenza virus $(500 \mathrm{CGA} / \mathrm{kg})$

Figures in parentheses indicate estimated minimum pyrogenic doses. See the text for the method for the estimation of the minimum pyrogenic dose.

pyrogenic activity was lost upon heating the material at $70 \mathrm{C}$ for $30 \mathrm{~min}$ (Fig. 1b), showing that the pyrogenic activity is heat labile and not attributable to endotoxin.

\section{Leukopenia Appearing within Several Hours after Influenza Virus Injection}

Figure $2 \mathrm{a}$ represents an example of peripheral leukocyte kinetics in mice within several hours after ip inoculation of 750 CCA of inactivated virus 712 . There was clear leukopenia in mice. The minimum level was seen around $4-5 \mathrm{hr}$ after inoculation of the material, in sharp contrast with leukopenia due to endotoxin, in which the minimum level was reached around $2 \mathrm{hr}$ after inoculation (Fig. 2b). The result of another experiment, in which a mixture of inactivated virus and endotoxin was inoculated (Fig. 2c), also indicated the two kinds of leukopenia occurring independently.

Figure 3 presents patterns of cell size distribution of peripheral leukocytes in 


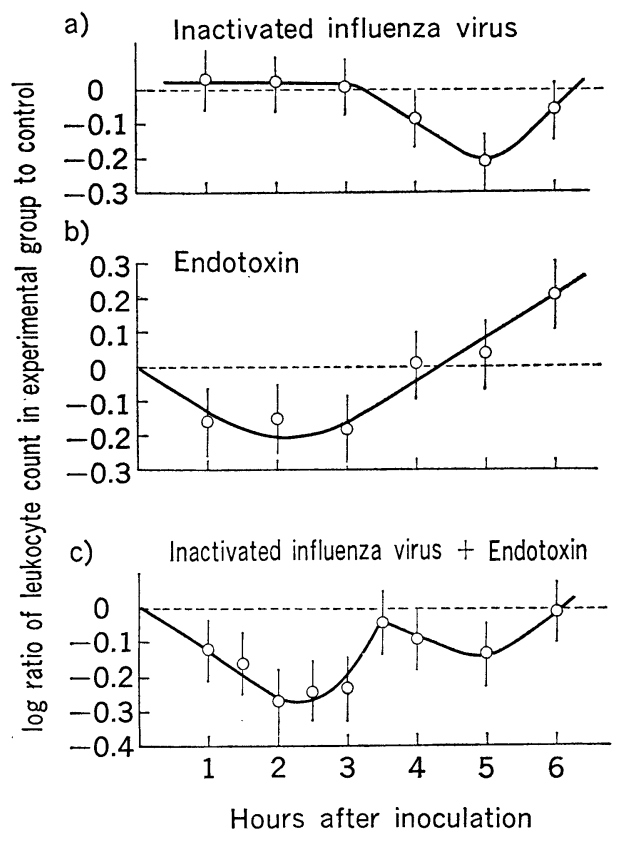

Fig. 2 Leukopenia in mice within several hours after ip injection of inactivated influenza virus or endotoxin.

Materials: 712 -inactivated influenza virus (750 CCA per mouse)

WE-1-endotoxin preparation (6.25 $\mu \mathrm{g}$ per mouse)

Each circle represents the geometric mean cell count of five experimental animals minus that of flve control animals.

Vertical bars represent the confidence interval of the mean at a probability $p=0.95$.

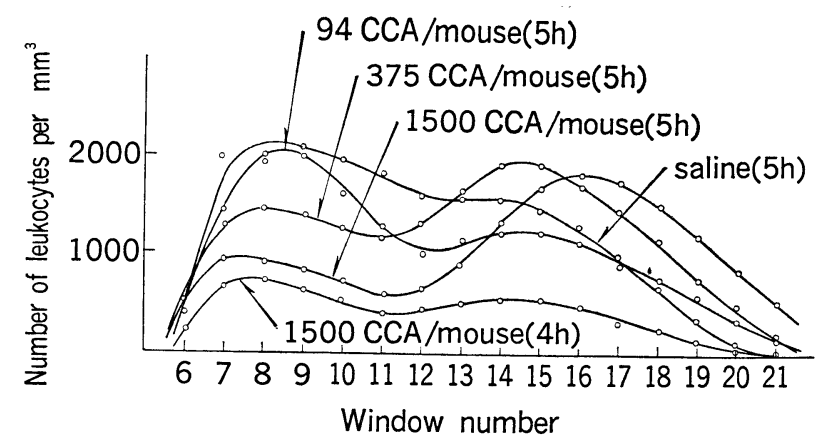

Fig. 3 Peripheral cell size distribution in mice 4 or $5 \mathrm{hr}$ after inoculation of different doses of live influenza virus.

Material: 714-live influenza virus.

Each curve represents sum of cell count of five mice. For the methods for cell sizing, see the text. 
mice obtained by electronic sizing performed 4 to $5 \mathrm{hr}$ after inoculation with graded doses of live influenza virus 714 or saline. When a relatively large dose (1500 CCA) was inoculated, both small- and large-sized cells decreased $4 \mathrm{hr}$ after inoculation but a distinct rightward shift in the second peak occurred $5 \mathrm{hr}$ after inoculation, showing the turn of leukopenia to leukocytosis. With a medium dose (375 CCA), small-sized cells decreased, while there was a certain increase or a somewhat rightward shift in large-sized cells. A small dose (94 CCA) did not induce any distinct change in the cell size distribution. It was confirmed by microscopical examinations that the large-sized cells were composed of large lymphocytes and granulocytes and that the small-sized cells were almost exclusively of small lymphocytes.

Though relative content of the large-sized cells was markedly higher in the mice used in the present experiments than those in the experiments with endotoxin (Kurokawa et al., 1974), there did not seem to be much difference between the pattern of change in leukocyte population due to endotoxin and that attributable to influenza virus. Mechanisms involved in changes in peripheral leukocyte population induced by influenza virus may be much complicated like those by endotoxin.

The peripheral leukocyte kinetics were followed by morphological examinations

a) Total peripheral leukocytes

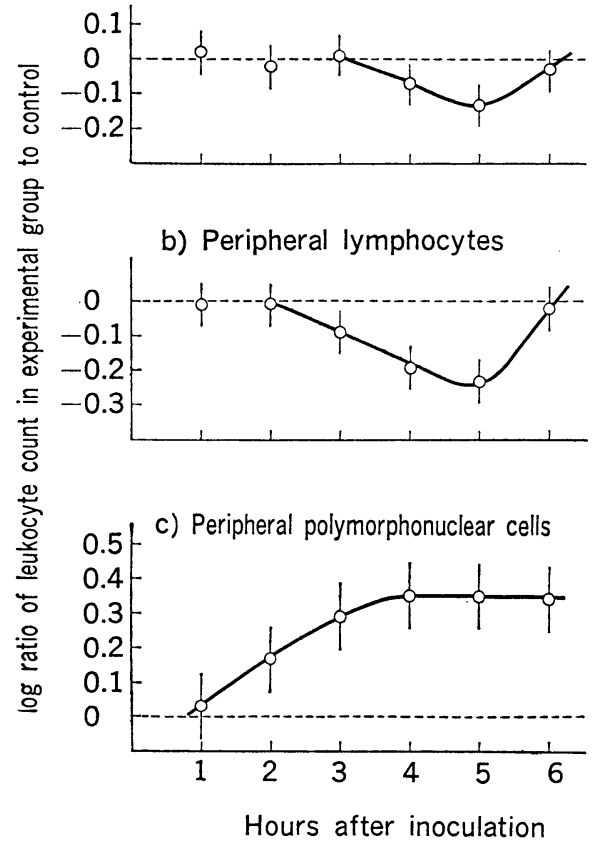

Fig. 4 Changes in lymphocytes and polymorphonuclear leukocytes in mice within several hours after ip injection of live influenza virus .

Material: B1-live influenza virus (167 CCA per mouse)

For $4 \mathrm{a}$, see the legends for Fig. 2, except the material. For $4 \mathrm{~b}$ and $4 \mathrm{c}$, each circle represents the geometric mean number of peripheral lymphocytes and that of polymorphonuclear leukocytes, respectively, of five experimental animals minus that of five control animals. 
of the mice inoculated with 167 CGA of B1, another live influenza virus. Daily electronic countings and morphological examinations of the peripheral blood leukocytes were carried out. Lymphocytes and polymorphonuclear leukocytes were counted from the percentage obtained by morphological examinations and the total cell count obtained by the electronic counter. The data (Fig. 4a, 4b and 4c) showed that the majority of cells decreasing by the dose used were lymphocytes, while increase of the polymorphonuclear cells was demonstrated to have already begun around $2 \mathrm{hr}$ after inoculation on morphological examinations.

This type of change in peripheral leukocyte population will hereafter be referred to as "early leukopenia", and a term "4-5-hour-lymphopenia" will also be used, if necessary, to differenciate it from leukopenia attributable to endotoxin, which

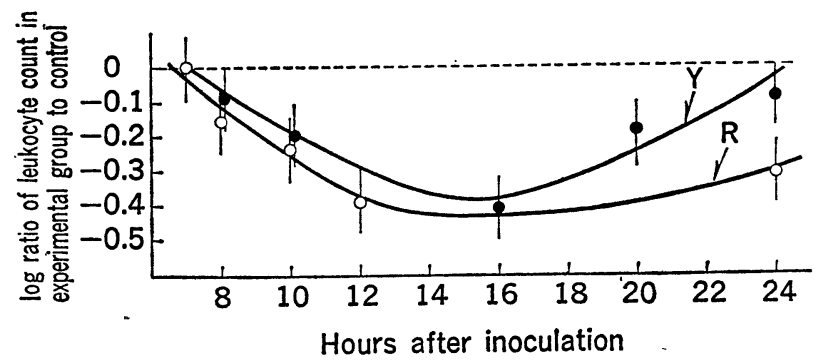

Fig. 5 Kinetics of change in peripheral leukocyte count in mice 6 to $24 \mathrm{hr}$ after iv or ip inoculation of inactivated influenza virus.

- Y-inactivated influenza virus (444 CGA per mouse $i v$ )

- $\mathrm{O}-\mathrm{R}$-inactivated influenza virus (560 CCA per mouse, $i p$ )

For other symbols, see the legend to Fig. 2.

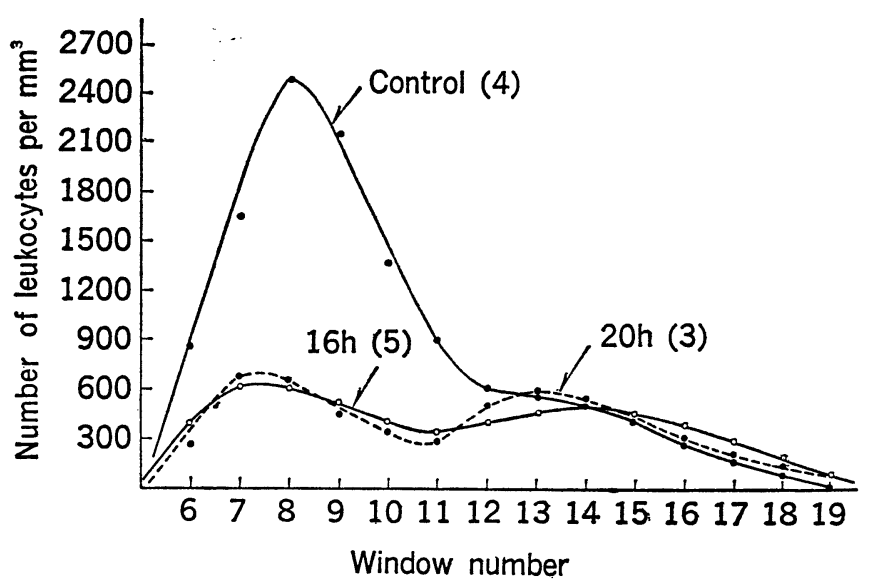

Fig. 6 Size distribution of peripheral leukocytes following ip inoculation of inactivated influenza virus.

Material: Y-inactivated influenza virus (444 CCA per mouse)

See the legend for Fig. 3 except for number of mice which was shown in parentheses on each curve. 
reaches its minimum level around $2 \mathrm{hr}$ after inoculation (Ishida, Ueno and Kurokawa, 1972; Ishida et al., 1973; Kurokawa et al., 1974).

\section{Late Appearing Peripheral Leukocyte Response to Influenza Virus}

Further observations of the change in peripheral leukocyte population found that the total number of peripheral leukocytes began to decrease again several hours after ip or iv inoculation of live or inactivated influenza virus, reached its minimum level around 12 to $18 \mathrm{hr}$ and then tended to increase to recover. Examples of the representative time course observed with inactivated viruses $Y$ and $R$ inoculated intravenously and intraperitoneally, respectively, are presented in Fig. 5.

Patterns of peripheral leukocyte sizing of individual mice 16 and $20 \mathrm{hr}$ after ip inoculation of 444 CCA of inactivated vaccine $\mathrm{Y}$ are displayed in Fig. 6. The first peak mainly composed of small-sized lymphocytes in the control mice lowered to a marked extent in the experimental group. Microscopical examinations revealed absolute as well as relative lymphopenia.

A term "late-lymphopenia" is applied to this type of leukopenia irrespective of the method to discriminate the decreased cells, by electronic sizing or by morphological examinations.

\section{Effects of Heat and Formaldehyde Treatments on Early Leukopenia and Late Lymphopenia-inducing Activities}

To test for the possible correlation between the agent for early leukopenia and that for late lymphopenia, effects of heat and formaldehyde treatments on both activities were investigated. Live influenza virus at a concentration of 4332 CCA per $\mathrm{ml}$ was heated at $70 \mathrm{C}$ for $30 \mathrm{~min}$ and tested for the activities. The early leukopenia-inducing activity was completely destroyed by the treatment (Fig. 7) but the lymphopenia-inducing activity was only partially affected (Table II). In this

TABLE II

Heat stability of the late lymphopenia-inducing activity

\begin{tabular}{lccc}
\hline & \multicolumn{2}{c}{ Peripheral leukocyte count } \\
\cline { 2 - 3 } & \multicolumn{2}{c}{ S5 $(2166 \mathrm{CCA} / \mathrm{mouse})$} & \multirow{2}{*}{ Saline } \\
\cline { 2 - 3 } & Untreated & Heated at $70 \mathrm{C}$ for $30 \mathrm{~min}$ & \\
\hline & $17 \times 10^{2} / \mathrm{mm}^{3}$ & $46 \times 10^{2} / \mathrm{mm}^{3}$ & $82 \times 10^{2} / \mathrm{mm}^{3}$ \\
& 22 & 60 & 120 \\
& 24 & 57 & 82 \\
& 29 & 69 & 100 \\
Geometric mean & 28 & 54 & 138 \\
95\% confidence interval & $18.1-30.8$ & 56.7 & 102.3 \\
\hline
\end{tabular}




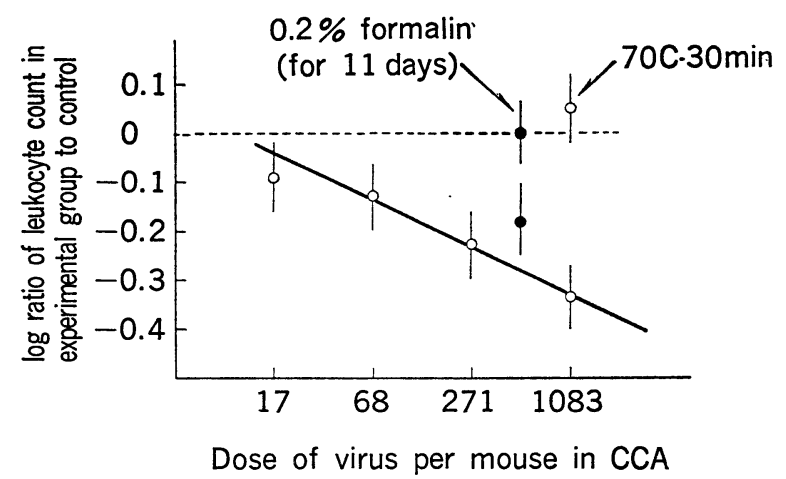

Fig. 7 Effects of heat and formaldehyde treatments on the early-leukopenia-inducing activity of live influenza virus.

Material: S5-live influenza virus.

Open and closed circles represent two separate experiments. For other symbols, see the legend for Fig. 2.

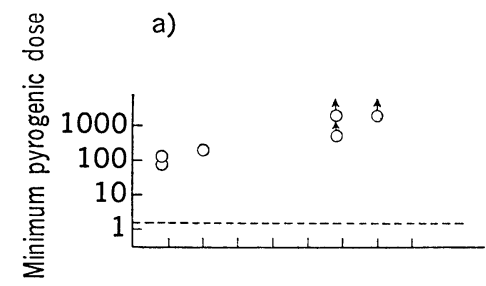

b)
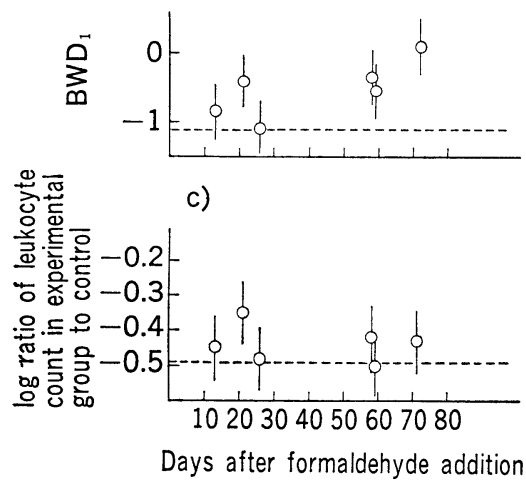

Fig. 8 Effects of formaldehyde on the representative activities of live influenza virus. Material: S5-live influenza virus.

Each circle represents the mean MPD of three rabbits in (a)*, the mean $\mathrm{BWD}_{1}$ of five mice in (b), or log ratio of leukocyte count in experimental group to that in control (c). $\mathrm{BWD}_{1}$ is the body weight on day 1 minus the preinoculation body weight.

Horizontal dotted line represents the mean of animals injected with the untreated starting materials in (a), (b) and (c).

The vertical bar represents the confidence interval of the mean at a probability $p=0.95$. * The circle with an arrow means that the test for pyrogenicity was negative at the indicated dose. 
respect, it is interesting that the virus pyrogen is also inactivated completely by heating at $70 \mathrm{C}$ for $30 \mathrm{~min}$ (Fig. 1b).

The same virus was added with formaldehyde to a concentration of $0.2 \%$ and kept at about 5 C. Samples were taken periodically and tested for pyrogenicity, the late lymphopenia-inducing activity and the mouse body weight-decreasing toxicity. The late lymphopenia-inducing activity did not change at all for 10 weeks. During this period, the pyrogenicity demonstrable in the rabbit at a dose of $20 \mathrm{CCA} / \mathrm{kg}$ (Fig. 1) disappeared and no pyrogenicity was demonstrable even at a concentration of 1,000-2,000 CGA (Fig. 8a), while the late lymphopenia-inducing activity was not affected at all during the observation period (Fig. 8a and 8c). The mouse body weight-decreasing toxicity disappeared almost completely by the end of the observation period (Fig. 8a and $8 b$ ).

In another experiment using the same material, addition of formaldehyde to $0.2 \%$ caused complete loss of the $4-5$ hour-leukopenia-inducing activity in 11 days (Fig. 7).

\section{Correlation between Body Weight-decreasing and Early Leukopenia-inducing Activities}

The preceding results suggested that the mouse body weight-decreasing toxicity might be correlated with pyrogenicity. It was interesting to see if the former activity is correlated with either the early leukopenia-inducing activity or the late lymphopenia-inducing activity. Figure 9 is an example showing parallelism in heat stability between the early leukopenia-inducing activity and mouse body weight-
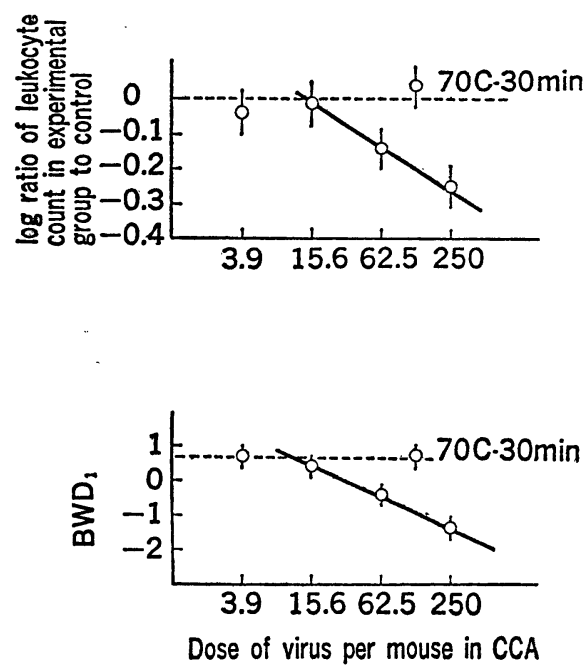

Fig. 9 Effect of heating on the early-leukopenia-inducing activity and body weightdecreasing activity of live influenza virus.

Material: B1-live influenza virus.

For BWD, see the legend for Fig. 8. For the symbols, see the legend for Fig. 2. 
decreasing activity of a live influenza virus. On the contrary, Fig. 10, in which pairs of the number of peripheral leukocyte $16 \mathrm{hr}$ after inoculation of live or inactivated influenza virus and $\mathrm{BWD}_{1}$ on individual materials were plotted, demonstrates little correlation between them.

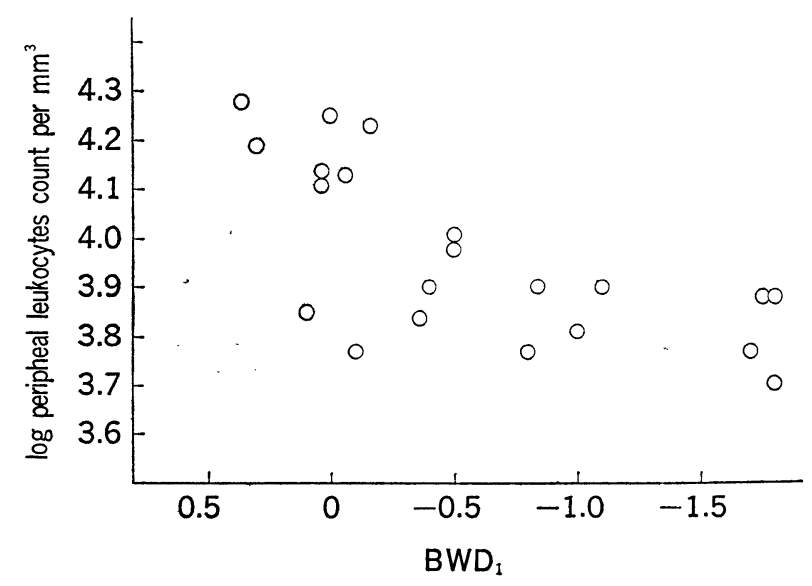

Fig. 10 Correlation between $\mathrm{BWD}_{1}$ and the peripheral leukocyte count $16 \mathrm{hr}$ after inoculation.

Materials: various kinds of live and inactivated influenza viruses.

For $\mathrm{BWD}_{1}$ see, the legend for Fig. 9. Each circle represents individual value.

\section{Discussion}

From the results of experiments on toxicities of live and inactivated influenza virus, the leukocytic response to influenza virus in mice may be divided into two phases, an early and a late appearing changes in peripheral leukocyte population. The agent responsible for the former response seems to be different from that for the latter one not only because of distinct difference in resistance to heat and formaldehyde but also because of dissociation of the two activities. The early leukopenia-inducing activity was completely destroyed by heating at $70 \mathrm{C}$ for $30 \mathrm{~min}$ or addition of formaldehyde at a concentration of $0.2 \%$ but the late lymphopeniainducing activity was not affected. Some influenza vaccines, showing neither heatlabile pyrogenicity nor the early leukopenia-inducing activity at a concentration of about $1,000 \mathrm{CCA} / \mathrm{ml}$ or higher, were found to induce late lymphopenia at a dose even smaller than 100 CGA per mouse.

A few data suggested possible correlation between the virus pyrogen and the early leukopenia-inducing activity. For instance, both the pyrogenicity and the early leukopenia-inducing activity were inactivated by heating at $70 \mathrm{C}$ for $30 \mathrm{~min}$ and by treatment with formaldehyde. Besides, a correlation between the temperature rise in rabbits and the 4-5-hour-leukopenia in mice was demonstrated with several influenza viruses by the authors (unpublished data).

In connection with the relationship between the virus pyrogen and the early 
leukopenia-inducing activity, comparison of the known properties of the virus pyrogen with those of endotoxin is worth discussing. Atkins and Snell (1965) listed the following features in which the responses induced by iv inoculation of myxoviruses, including influenza viruses, differed from those associated with endotoxin. (1) There was a difference in the latent period, as was mentioned above. (2) Virusinduced fever was associated with progressive and prolonged lymphopenia, whereas endotoxins produced change predominantly in the number of circulating granulocytes (Harris and Henle, 1948; Bennett et al., 1949; Wagner et al., 1949). (3) Myxovirus lost its pyrogenic activity when combined in vitro with the specific immune serum (Bennett et al., 1949; Wagner et al., 1949; Atkins and Huang, 1958), while the toxic properties (including pyrogenicity) of endotoxin were not modified with homologous antibody. The lymphocytopenic effect of the virus was also neutralized by rabbit type-specific immune serum (Harris and Henle, 1948).

In relation to the item (2), there were no essential differences between influenza virus and endotoxin in the pattern of the resulting changes in peripheral leukocyte population in mice after ip inoculation except for the latent period. It is interesting that the latent period before onset of virus fever is longer than that of endotoxin fever. In relation to the item (3), we have some data suggesting that our antisera prepared against influenza virus were able to neutralize both the early leukopeniaand late lymphopenia-inducing activities.

On the other hand, the mechanisms of fever induction by myxoviruses in rabbits appear to be essentially the same as those by endotoxin (Atkins and Snell, 1965). It may be interesting to see whether the virus pyrogen or the agent responsible for early leukopenia has any of the properties of endotoxin other than the mouse leukocytic response-inducing- and mouse body weight-decreasing activities.

During the course of influenza in man induced by deliberate inoculation of virus, neutropenia and lymphopenia (Smorodintseff et al., 1937) or leukopenia with relative lymphocytosis (Henle, Henle and Stokes, 1943; Henle et al., 1946) were demonstrated almost consistently, though lymphocytosis was observed in an early stage (Douglas et al., 1966). It remains unclear whether there are any relationship between the leukocytic responses in man mentioned just above and those in mice.

Some viral infections other than influenza in experimental animals have been reported also to alter both rate and absolute number of peripheral leukocytes (Gresser and Lang, 1966; Wheelock and Toy, 1973). Of several reports concerning lymphopenia in mice caused by Newcastle Disease virus (NDV), the one by Woodruff and Woodruff (1970) is of particular interest in respect of the time course of the change in the leukocyte population in mice after the iv inoculation. According to the report, lymphopenia was demonstrated $6 \mathrm{hr}$ after iv inoculation of $4 \times 10^{8}$ $50 \%$ egg infective doses of an NDV suspension and the minimum level of the lymphopenia was reached in 12 to $24 \mathrm{hr}$. These characteristics seem to be similar to the time course of lymphopenia in mice observed in the present study.

In addition, Woodruff and Woodruff (1970) described also marked granulocytosis in mice $6 \mathrm{hr}$ after intravenous inoculation of NDV, though no observation was made on peripheral leukocytes within $6 \mathrm{hr}$. It is unlikely that granulocytosis was induced by the same agent as responsible for lymphopenia, because, according 
to their report, an ultraviolet irradiated NDV virus preparation did not induce granulocytosis but retained the lymphopenic effect. Siegert and Braune (1964) found that ultraviolet irradiation destroyed NDV pyrogenicity. These findings might also suggest that the agent of NDV responsible for lymphopenia is different from the NDV pyrogen.

Several kinds of untoward reactions following influenza vaccination in man have been known; systemic reactions such as fever and local reactions such as erythema and induration (Mostow et al., 1969, 1970; Ruben and Jackson, 1972). In studies on untoward reactions of influenza vaccine, the febrile response has often been employed as a representative one (Salk, 1948; Davenport et al., 1964; Brandon et al., 1967, 1969; Reimer et al., 1967; Duxbury, Hampson and Sievers, 1968). The fever might be accounted for by the virus pyrogen. However, as a certain portion of eggs used for vaccine production is not always free from bacterial contamination (Perkins, 1969). Endotoxin derived from contaminating bacteria might partly be responsible for the fever and other untoward reactions following influenza vaccination. The two factors causing febrile reaction must separately be defined.

In connection with such local reactions as erythema and induration, there have been only a few data on the agent or agents responsible for those local reactions. Endotoxin per se can cause erythema and induration in the skin of experimental animals and man. But in the positive rate and severity, these local reactions in man did not always behave parallelly with febrile reactions (Mostow et al., 1969, 1970; Ruben and Jackson, 1972). The Subcommittee on Untoward Reactions of the Research Committee of Influenza Vaccine (Research Committee on Influenza Vaccine, 1974) has experienced that, with ether-treated influenza vaccines having been shown at a concentration of 10,000 CCA per $\mathrm{ml}$ to be free from the early leukopenia- and the late lymphopenia-inducing activities and the leukopenia-inducing activity attributable to endotoxin in mice, little systemic reaction was observed in man even at a dose of 5,000 CCA, but local reactions such as erythema and induration were observed at much smaller doses and that the size and positive rate of the local reactions seemed to be dose dependent. Therefore, a toxic agent different from any of the toxic substances mentioned in this report should be looked for, provided that the local reactions are not of immunological nature. There is a report suggesting that a delayed hypersensitivity reaction might be caused by a component(s) of influenza virus itself (Habershon et al., 1973).

\section{ApPendix}

By use of the data (see the attached figure) borrowed from Dr. S. Kanoh, the regression coefficient of the temperature rise in the rabbit by influenza virus against log dose was calculated to be 1.1541 . Deviations from linearity of the regression line was not significant at a probability $\mathrm{p}=0.01$. 


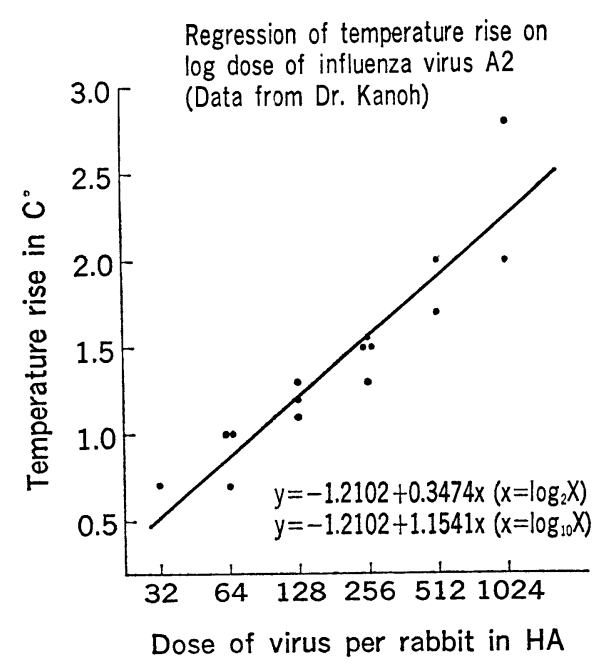

Appendix Fig. Regression of temperature rise on log dose of live influenza virus, strain A2 (Data from Dr. Kanoh)

Each circle represents individual value.

Calculation of the regression coefficient of Influenza virus pyrogen

\begin{tabular}{lcccc}
\hline $\begin{array}{l}\text { Nature of } \\
\text { variation }\end{array}$ & $\begin{array}{c}\text { Sum of } \\
\text { squares }\end{array}$ & $\begin{array}{c}\text { Degree of } \\
\text { freedom }\end{array}$ & $\begin{array}{c}\text { Mean } \\
\text { square }\end{array}$ & $\begin{array}{c}\text { Variance } \\
\text { ratio }\end{array}$ \\
\hline Regression & 3.8152 & 1 & 3.8152 & $60.5589^{* *}$ \\
Linearity & 0.1569 & 4 & 0.0392 & \\
\hline Between doses & 3.9721 & 5 & & \\
Error & 0.5669 & 9 & $0 . .630$ & \\
\hline Total & 4.5390 & 14 & & \\
\hline
\end{tabular}

** significant at $\mathrm{p}=0.01$

\section{Aaknowledgement}

The authors wish to express their heartfelt thanks to Drs. I. Yoshioka and O. Igarashi, the Kitasato Institute, Tokyo, Drs. T. Koide and M. Kato, the Research Foundation for Microbial Diseases of Osaka University, Kanonji, Kagawa Prefecture, Drs. J. Kaneko and S. Matsuyama, the Takeda Pharmaceutical Ind. Ltd., Hikari Plant, Hikari, Yamaguchi Prefecture for supplying materials, to Dr. S. Kanoh, National Institute of Hygienic Science, Osaka Branch, Osaka for allowing us to use his data on pyrogenicity tests of influenza virus. They are also indebted to Dr. H. Fukumi and other members of the Research Committee on Influenza Vaccine for valuable advices and discussions. Thanks are due to Mrs. C. Osugi, Mr. Y. Shimazaki and Mr. I. Funasaka for technical assistance.

\section{REFERENGES}

Atrins, E. And Haung, W. C. (1958): Studies on the pathogenesis of fever with influenza viruses. III. The relation of tolerance to the production of endogenous pyrogen. J. Exptl. Med., 107, 415-435. 
Atkins, E. And Snell, E. S. (1965): Fever. p. 495-534. In B. W. Zweifach, L. Grant and R. T. McCluskey [ed.], The Inflammatory Process, Academic Press, New York and London.

Bennett, I. L., Jr., Wagner, R. R. and Lequire, V. (1949): Pyrogenicity of influenza virus in rabbits. Proc. Soc. Exptl. Biol. Med., 71, 132-133.

Brandon, F. B., Barrett, G. D., Jr., Hook, A. E. and Lease, G. O. (1967) : Human febrile response to influenza virus or its ether isolated hemagglutinins. Proc. Soc. Exptl. Biol. Med., $125,683-686$.

Brandon, F. B., Cox, F., Quinn, E., Timm, E. A. and McLean, I. W. (1969): Influenza immunization. Clinical studies with ether-split subunit vaccines. Bull. WHO, 41, 629-637.

Davenport, F. M., Hennessy, A. V., Brandon, F. M., Webster, R. G., Barrett, C. D., Jr. and Lease, G. O. (1964): Comparisons of serologic and febrile responses in humans to vaccination with influenza A viruses or their hemagglutinins. J. Lab. Clin. Med., 63, 5-13.

Douglas, R. G., Alford, R. H., Cate, T. R. and Gouch, R. B. (1966): The leukocyte response during viral respiratory illness in man. Ann. Intern. Med., 64, 521-528.

Duxbury, A. E., Hampson, A. W. and Sievers, J. G. M. (1968): Antibody response in humans to deoxicholate-treated influenza virus vaccine. J. Immunol., 101, 62-67.

French, E. L. (1952): The pyrogenic effect of the influenza-mumps group of viruses in the laboratory rabbit. Australian J. Exp. Biol. Med. Sci., 30, 479-488.

Gresser, I. AND LANG, D. J. (1966): Relationships between viruses and leucocytes. p. 62130. In J. L. Melnick [ęd.], Progr. med. Virol., 8, S. Karger, Basel.

Habershon, R. B., Molyneux, M. E., Slavin, G., Loewi, G. and Tyrrell, D. A. J. (1973) : Skin tests with influenza virus. J. Hyg., 71, 755-760.

Harris, S. and Henle, W. (1948): Lymphocytopenia in rabbits following intravenous injection of influenza virus. J. Immunol., 59, 9-20.

Henle, W., Henle, G. and Stokes, J., Jr. (1943): Demonstration of the efficacy of vaccination against influenza type A by experimental infection of human beings. J. Immunol., $46,163-175$.

Henle, W., Henle, G., Stokes, J., Jr. and Maris, E. P. (1946) : Experimental exposure of human subjects to viruses of influenza. J. Immunol., 52, 145-165.

Istida, S. (1968): Characterization of the body weight-decreasing toxicities in mice by the lymphocytosis-promoting factor and the heat-labile toxin of $B$. pertussis and endotoxin. Japan. J. Med. Sci. Biol., 21, 115-135.

Ishida, S. AND KurokawA, M. (1971): Determination of lymphocytosis-promoting factor. Medicine and Biology, 83, 117-122. (text in Japanese)

Ishida, S., Ueno, G. AND Kurokawa, M. (1972): Determination of endotoxin based upon the change of peripheral leukocyte count in mice. Medicine and Biology, 85, 113-116. (text in Japanese)

Ishida, S., Goto, N., Ueno, G., Funasaka, I., Kuratsuka, K. and Kurokawa, M. (1972) : Determination of endotoxin by change of peripheral leukocyte count in mice and its correlation with pyrogenic activity. Medicine and Biology, 85, 169-172. (text in Japanese)

KanoH, S. AND KaWAsaki, H. (1966): Studies on myxovirus pyrogen. I. Interaction of myxovirus and rabbit polymorphonuclear leucocytes. Biken J., 9, 177-184.

Kurokawa, M., Ishida, S., Goto, N. and Kuratsuka, K. (1974): A new method for biological assay of endotoxin using change in peripheral leukocyte population in mice as a response. Japan. J. Med. Sci. Biol., 27, 173-189.

Ministry of Health and Welfare, Japanese Government (1973): Minimum Requirements for Biological Products. English edition.

Mostow, S. R., Schoenbaum, S. C., Dowdle, W. R., Coleman, M. T. and Kaye, H. S. (1969): Studies with inactivated influenza vaccines purified by zonal centrifugation. I. Adverse reactions and serological responses. Bull. WHO, 41, 525-530.

Mostow, S. R., Sahoenbaum, S. G., Dowdle, W. R., Coleman, M. T., Kaye, H. S. and Hierholzer, J. C. (1970): Studies on inactivated influenza vaccines. II. Effect of increasing dosage on antibody response and adverse reactions in man. Am. J. Epidemiol., $92,248-256$.

Perkins, F. T. (1969): Control of influenza vaccine, with special reference to experience in the United Kingdom. Bull. WHO, 41, 554-555.

Reimer, G. B., Baker, R. S., van Frank, R. M., Newlin, T. E., Gline, G. B. and Anderson, N. G. (1967): Purification of large quantities of influenza virus by density gradient centrifugation. J. Virol., 1, 1207-1216. 
Research Committee on Influenza Vaccine (1973): Proceedings of the 12th Meeting of the Research Committee on Influenza Vaccines. Association of Bacteriological Producers, Tokyo. (text in Japanese)

Ruben, F. L. AND JAGKson, G. G. (1972): A new subunit influenza vaccine: acceptability compared with standard vaccines and effect of dose on antigenicity. J. Infect. Dis., 125, $656-664$

SALK, J. E. (1948): Reactions to concentrated influenza virus vaccines. J. Immunol., 58, 369-395.

Siegert, R. And Braune, P. (1964): The pyrogens of myxoviruses. I. Induction of hyperthermia and its tolerance. Virology, 24, 209-217.

Siegert, R., Shu, H. L., Pollmann, W. and Menzed, H. (1967): Untersuchungen über Viruspyrogene. I. Mitt.: Versuche zur Abtrennung des pyrogenen Prinzips von Myxoviren. Z. Naturforschg., 22b, 155-158.

Smorodintseff, A. A., Tughinsky, M. D. Drobyshevskaya, A. I., Korovin, A. A. ANd Osetroff, A. I. (1937): Investigation on volunteers infected with the influenza virus. Am. J. Med. Sci., 194, 159-170.

WaGner, R. R., Bennet, I. L., Jr. And LeQuire, V. S. (1949): The production of fever by influenza viruses. I. Factors influencing the febrile response to single infections of virus. J. Exptl. Med., 90, 321-334.

Westphal, O. AND JANN, K. (1965): Bacterial lipopolysaccharides. Extraction with phenol-water and further applications of the procedure. p. 83-91. In R. L. Whistler, J. N. BeMiller and M. L. Wolfrom [ed.], Methods in Carbohydrate Chemistry, Vol. V, Academic Press, New York.

Wheelock, E. F. ANd Toy, S. T. (1973): Participation of lymphocytes in viral infections. p. 123-184. In Advances in Immunology, Vol. 16, Academic Press, New York.

WOODRUFF, J. F. AND WoodRufF, J. J. (1970): Virus-induced alterations of lymphoid tissues. I. Modification of the recirculating pool of small lymphocytes by Newcastle Disease virus. Cellular Immunol., 1, 333-354. 